January 2014

\title{
Strict Liability in the Shadow of Juries
}

Darryl K. Brown

University of Virginia School of Law

\section{Recommended Citation}

Darryl K Brown, Strict Liability in the Shadow of Juries, 67 SMU L. REV. 525 (2014)

https://scholar.smu.edu/smulr/vol67/iss3/8

This Article is brought to you for free and open access by the Law Journals at SMU Scholar. It has been accepted for inclusion in SMU Law Review by an authorized administrator of SMU Scholar. For more information, please visit http://digitalrepository.smu.edu. 


\title{
STRICT Liability IN THE SHADOW OF JURIES
}

\author{
Darryl K. Brown*
}

\begin{abstract}
American and English criminal law is characterized by wider use of strict liability than one finds in the criminal law of many European jurisdictions. With respect to English law, scholars have suggested that the use of lay juries explains the prevalence of strict liability offenses. This paper investigates that idea in American law and finds some evidence for it. Courts and legislatures sometimes worry that mens rea is difficult to prove when the only available evidence is circumstantial-it must be inferred from conduct and circumstances. Just as the evidence rules reflect a concern with the limits of jurors' abilities to handle certain kinds of evidence, the rules regarding strict liability as well as reverse burdens of proof (under which defendants must prove defenses) manifest a concern that juries are worse than judges at inferring culpability from available evidence. One way to address this deficiency is to eliminate the requirement for mens rea altogether.

But then what safeguards remain to ensure that only the culpable are criminally punished? The answer in American law, broadly, is that adversarial criminal procedure is thought to compensate for this deficiency in substantive criminal law. Courts identify, somewhat obliquely, two procedural components in particular: the use of prosecutorial discretion, and, paradoxically, the jury. While courts are somewhat skeptical of the jury's capacity to accurately recognize proof of culpability, they profess faith in the lay jury's "common sense" instincts-or political judgments-to prevent convictions of the non-culpable. On that view, strict liability addresses the jury's weakness regarding a challenging issue of proof, while the jury's purportedly strong capacity for normative judgment, in turn, provides a safeguard against unjustified punishment.
\end{abstract}

\section{INTRODUCTION}

LL American criminal law codes - as well as that of England-
include innumerable offenses that lack mens rea requirements
for one or more elements. The category of regulatory or public-

* O.M. Vicars Professor of Law and E. James Kelly, Jr. Class of 1965 Research Professor, University of Virginia School of Law; brownd@virginia.edu. 
established, but strict liability extends well beyond that class. The same is true of procedural rules that in practical effect can be closely analogous to strict liability offenses. "Reverse proof burdens" place the burden of proving some fact relevant to blameworthiness and liability on defendants rather than the state; they are especially common for so-called affirmative defenses such as self-defense. ${ }^{1}$ Strict liability and reverse burdens sometimes work in combination, highlighting their functional similarity. ${ }^{2}$ For some offenses, the state's proof of a strict liability offense might be defeated by a defendant who carries the burden of proving his lack of culpability, e.g., by proving he used reasonable care. ${ }^{3}$ That structure converts strict liability, in effect, into a rebuttable presumption of mens rea upon the prosecution's proof of actus reus.

This would seem curious if it were not so familiar. For one, both types of rules undermine the culpability principle of actus non facit reum nisi mens sit rea-no criminal liability without proof of fault, which is implemented by requiring the state to prove beyond reasonable doubt the union of conduct and blameworthy state of mind. ${ }^{4}$ For another, the

1. They are employed as well for issues external to culpability, such as statutes of limitations. See Smith v. United States, 133 S. Ct. 714, 717 (2013) (affirming placement of burden on defendant to prove withdrawal from conspiracy outside the statute of limitations period).

Reverse proof burdens can take two forms. When defendants bear the burden of persuasion, the rule authorizes conviction unless the defendant proves the facts (e.g., use of force in self-defense) on which he bears that burden. On this distinction, see Ct. of Ulster Cnty. v. Allen, 442 U.S. 140, $158 \mathrm{n} .16$ (1979). The burden of proof is widely placed on defendants for many affirmative defenses such as self-defense, insanity, withdrawal from conspiracy, and statute-of-limitations bars. See Smith, $133 \mathrm{~S}$. Ct. at 719 (on conspiracy and statutes of limitations claims, and issues that defeat liability by negating proof of required elements, such as intoxication to negate specific intent). See John Calvin Jeffries, Jr. \& Paul B. Stephan, III, Defense, Presumptions, and Burden of Proof in Criminal Law, 88 YALE L.J. 1325 (1979) (surveying such rules); George Fletcher, Two Kinds of Legal Rules: $A$ Comparative Study of Burden-of-Persuasion Practices, 77 Y ALE L.J. 880 (1968) (same); Arthur Murphy, The Intoxication Defense: An Introduction to Mr. Smith's Article, 76 Dick. L. Rev. 1, 10 (1971-72) (noting Ohio law that puts burden of persuasion on defendants regarding intoxication); Richard J. Bonnie, ET AL. CRIMINAL LAW 230 (3rd ed. 2010) (estimating that "[p]erhaps as many as half the states" place the burden of persuasion on defendants to disprove specific intent with intoxication evidence). If the defendant bears only the burden of production (or "going forward"), an issue is removed from consideration unless defendant presents enough evidence to raise it as a factual dispute. See, e.g., People v. Cleaves, 229 Cal. App. 3d 367, 375 (4th App. Dist. 1991) (in homicide trial, affirming trial court's refusal to give a jury instruction on lesser charge of assisting a suicide because defendant had not met his burden to produce evidence providing "some basis" for the instruction).

2. A third procedural rule has a similar functional effect: Evidentiary presumptions, or inferences, ease the state's burden of proof by authorizing judges and juries to find one fact to be proven by inference from proof another fact. For example, an explicit rule may inform juries that proof of possession of drugs (say, in defendant's car or luggage) permits an inference of knowing possession.

3. See United States v. Park, 421 U.S. 658,672 (1975) (strongly implying that a strict liability offense permits a defense that defendant was "powerless to prevent" the prohibited harm).

4. Fowler v. Padget, [1798] 7 Term Rep. 509, 101 ER 1103 (Lord Kenyon, C.J.) ("II]t is a principle of natural justice, and our law, that ... [t] he intent and the act must both occur to constitute the crime."). In Blackstone's description, for criminal liability "there must be first a vicious will, and secondly an unlawful act consequent upon such vicious will." 4 William Blackstone, Commentaries *21. See also United States v. Morissette, 
American and English criminal justice systems are fairly distinctive in this respect. A generation ago, George Fletcher described how English, American, and German criminal law systems in the nineteenth century all relied on rules that placed the proof burden for some issues on defendants. Beginning in the late nineteenth century, German reforms eventually did away with use of reverse-proof burdens. Fletcher initially thought English and American law were headed the same way and that this represented a general shift in Western legal systems. ${ }^{5}$ But he subsequently found Anglo-American reforms to be much more partial and ambivalent; ${ }^{6}$ a few states abandoned use of reverse-burden rules that were established in common law, but many never did. Nothing in the last thirty years has changed Fletcher's picture of American or English criminal law on this point. The story regarding strict liability is much the same. ${ }^{7} \mathrm{Ger}$ man criminal law today rarely employs strict liability in crime definitions and has no class of offenses equivalent to Anglo-American public welfare crimes. Strict liability has diminished even in other common law countries, notably Canada. ${ }^{8}$

What accounts for the distinctiveness of Anglo-American criminal law on these points? Perhaps the most significant explanation in the scholarly literature, which is focused on strict liability, is that Anglo-American criminal law operates on a different, weaker principle of culpability than that which prevails in Germany or elsewhere. Both English and American scholars recognize that their criminal law does not abide by the "principle of correspondence," which requires proof of fault for every material element of an offense so that punishment is imposed in proportion to a wrongdoer's culpability. Much of Anglo-American criminal law instead follows a much weaker culpability premise, which requires only proof of fault for some wrongdoing (e.g., an offense conduct element), after which punishment may increase without regard for a wrongdoer's fault as to

342 U.S. 246, 254 (1952) (distinguishing ordinary crimes from regulatory or public-welfare offences). See generally Jeffries \& Stephan, supra note 1 (describing tensions between reverse burdens and evidentiary presumptions and requirements that the state prove individual culpability and extensively analyzing of case law).

5. George Fletcher, Rethinking Criminal Law \$§ 7.2-7.3 (1978); George Fletcher, Two Kinds of Legal Rules: A Comparative Study of Burden-of-Persuasion Practices, 77 Y ALE L.J. 880 (1968).

6. In his 1968 article, Fletcher depicted Anglo-American common law as having started down the same reform path as Germany. The U.S. was less far along that path, but his implication was that the trend was uniform across western legal systems. When he took up the same topic in his landmark book ten years later, he revised his assessment, recognized U.S. reform had not progressed, and described a divergence of German and AngloAmerican criminal law on this point. Compare Fletcher, supra note 5, with FLeTCHER, supra note 5.

7. See Andrew Ashworth, Principles of Criminal Law 76 (6th ed. 2007) (strict liability articles); Fletcher, supra note 5 (for reverse-burdens point).

8. See Jeroen Blomsma, Mens rea and Defences in European Criminal Law 210-31 (Intersentia 2012) (analyzing use or rejection of strict liability in European common law and civil law states); Darryl K. Brown, Public Welfare Offenses, in OxFORD Handbook of Criminal Law (Markus Dubber ed.) (forthcoming 2014) (comparing strict liability usage in common law and European civil law jurisdictions and noting that Germany uses civil rather than criminal sanctions for regulatory offenses). 
aggravating elements (e.g., unknown circumstances or unintended results) ${ }^{9}$

But there is another possible explanation, suggested by English and European scholars: We adopt strict criminal liability because we use lay juries. "It seems very likely," Professors Spencer and Pedain have suggested, "that a distrust of juries is an unspoken element that lies behind a range of judicial decisions that, over the years, have made inroads on the culpability principle."10 After describing German and French tribunals dominated by professional judges, they conclude that "[o]n a practical level, it is therefore easy to see why the need to prove fault at the trial puts much less of a strain on the operation of the institutions of criminal justice on the Continent than comparable requirements do in England."11 A German scholar also focused on English rather than American criminal process has recently suggested much the same. ${ }^{12}$ The argument has some intuitive appeal. Concern about proving facts arises against the background of who decides whether facts are proven. Fears that certain facts are hard to prove are partly concerns about fact finders rather than evidence. If lawmakers think jurors are likely to get facts wrong, they can often remove fact questions from jurors (strict liability), make facts easier to find (evidentiary presumptions), or shift the risk of fact-finding error onto defendants (reverse burdens).

My aim is to investigate this claim primarily in the context of American criminal law, especially against more familiar and explicit justifications for strict liability. My conclusion is that the jury is a contributing cause for both the wide acceptance of strict liability and the use of reverse-proof burdens for two broad reasons that I develop below. The first is that there is much other evidence of our distrust of juries in American legal systems,

9. See Ashworth, supra note 1; Victor TAdros, Criminal Responsibility 93-97 (2005); Blomsma, supra note 8, at 210-31 (discussing the correspondence principle in relation to strict liability). The correspondence principle is generally taken as aspirational, rather than a descriptive, in English criminal law. Arguments for a weaker proportionality principle suggest that a culpable wrongdoer may have forfeited an entitlement to punishment in accord with fault due to a change in "normative position." See Jeremy Horder, $A$ Critique of the Correspondence Principle of Criminal Law, 1995 CRIM. L. REV. 759; see also Kenneth W. Simons, Is Strict Criminal Liability in the Grading of Offenses Consistent with Retributive Desert?, 32 OxFORD J. Legal STUD. 445 (2012) (describing and assessing nonadherence to the correspondence principle in English and American criminal punishment); Darryl K. Brown, Criminal Law Reform and the Persistence of Strict Liability, 62 DukE L.J. 289 (2012) (discussing the same, under the label "threshold liability"). One manifestation of this is the exceedingly weak requirement of proportional punishment in American constitutional law, where proportionality limits are meaningful only at the extremesmostly regarding capital punishment and life incarceration of juvenile offenders. German constitutional law, by contrast, includes a much stronger requirement of proportionality in criminal punishment. On the latter, see Thomas Weigend \& Jenia Iontcheva Turner, The Constitutionality of Negotiated Criminal Judgments in Germany, 15 GERMAN L.J. (2014), available at http://www.germanlawjournal.com/index.php?pageID=11\&artID=1611.

10. Spencer \& Pedain, Approaches to Strict and Constructive Liability in Continental Criminal Law, in Appraising Strict Liability 273 (Andrew Simester, ed. 2005).

11. Spencer \& Pedain, supra note 10, at 274.

12. See Mattias Hoerster, Die Strict Liability des englischen StrafrechtsZugleich eine Gegenuberstellung mit dem deutschen Straf- un OrdnungSWIDRIGKEITENRECT 29-44 (2009) (cited in Blomsma, supra note 8, at 208-20). 
so we should not be surprised that strict liability - and its functional counterpart, reverse-proof burdens-finds a rationale in counteracting distrust of an institution that cannot be fully abolished. The second, paradoxically, rests a certain kind of trust in juries. The implication is that juries-and our criminal procedure regime more broadly-make strict liability more tolerable. Procedural requirements, including jury fact-finding authority, help to alleviate anxieties about possible injustices from substantive criminal laws that permit liability on the basis of insufficient culpability. That calculus, in turn, reflects a larger American (perhaps Anglo-American) reliance on procedure over substantive law as the primary safeguard against injustice.

Part II recounts longstanding concerns about the difficulty of certain kinds of facts and how strict liability, reverse proof burdens, and presumptions respond to those concerns. Part III describes the divergent assumptions about juries' and judges' relative strengths and weaknesses. Juries' political instincts and "common sense" garner more trust than that of judges. But assumptions about juries' common-sense capacity for factfinding have some curious limits. On certain tough, factual issues, judges' experience is thought to give them better insight to make accurate factual inferences from circumstantial evidence. Part IV unpacks how these devices address juries' perceived weaknesses at some risk to permitting punishment without fault. Part V argues that those risks are understood to be minimized by the protections of adversarial process, common law practices, and constitutional criminal procedure.

\section{WORRIES ABOUT JURIES}

\section{A. Contrasting Traditions of Criminal Juries}

The traditions of criminal juries shared by all common law systems are well entrenched in the federal and state constitutional law. The U.S. Supreme Court has often painted a rosy portrait of the criminal jury as "fundamental to the American scheme of justice" and "among those 'fundamental principles of liberty and justice which lie at the base of all our civil and political institutions.' "13 Part of the jury's function rests on a commitment to integrating lay citizens' common sense and judgment into the adjudicative task of assessing evidence and finding facts. The jury right rests on "insistence upon community participation in the determination of guilt or innocence" 14 and serves "to maintain a link between contemporary community values and the penal system ...."15 But the jury also serves a larger political purpose: "to prevent oppression by the Gov-

13. Duncan v. Louisiana, 391 U.S. 145, 148-49 (1968) (quoting Powell v. Alabama, 287 U.S. 45,67 (1932)) (internal quotation marks omitted).

14. Id. at 156 .

15. Witherspoon v. Illinois, 391 U.S. 510,519 n.15 (1968) (also noting the state has a strong interest in having the jury "express the conscience of the community on the ultimate question of life or death."). See also Crawford v. Washington, 541 U.S. 36, 62, 68-69 (2004) (emphasizing the jury's role in assessing trial evidence). 
ernment"16 and "to guard against the exercise of arbitrary power-to make available the commonsense judgment of the community as a hedge against the overzealous or mistaken prosecutor and in preference to the professional or perhaps overconditioned or biased response of a judge." 17 Jurors' advantages over judges, then, lie in their access to the common sense of ordinary citizens and in a faith that their political judgment will serve as a more reliable check on inappropriate enforcement efforts than judges.

Despite this veneration of the criminal jury, constitutional doctrine and the common law also contain a deep counter-tradition about juries that is fully evident in American constitutional and statutory law. At least since Wigmore, one site for this counter-tradition is the law of evidence, which manifests considerable distrust of the jury's capabilities to assess evidence and therefore to function as reliable fact-finders. Evidence law is replete with complicated exclusionary rules, many of which are motivated by worries that jurors will misuse or be misled by certain kinds of evidence. Familiar examples include many forms of hearsay, ${ }^{18}$ information about a defendant's prior criminal convictions, ${ }^{19}$ use of poor quality substitutes for original documents (the "best evidence" rules), ${ }^{20}$ and any probative evidence that also would be unfairly prejudicial if misused. ${ }^{21}$ Other rules authorize evidence to assist jurors on topics not within ordinary lay knowledge. An obvious example is certain kinds of expert testimony, such as that on "social frameworks" or eyewitness reliability, which is intended to improve jurors' judgments on issues about which contextual knowledge is usually thin or misconceptions are widespread. ${ }^{22}$

These concerns extend to sources of information beyond admissible evidence. Rules against exposure to publicity about the case before and during trial also reflect a similar judgment about jurors' inabilities to assess the reliability of sources or to disregard irrelevant information..$^{23}$ Other rules outside the evidence code likewise rest on a dim view of ju-

16. Duncan, 391 U.S. at 155.

17. Taylor, 419 U.S. 522, 530 (1975) (citing Duncan, 391 U.S. at 155-56). See also Apprendi v. New Jersey, 530 U.S. 466, 477 (2000) (the jury "guard[s] against a spirit of oppression and tyranny on the part of rulers [and serves] as the great bulwark of civil and political liberties"); Neder v. United States, 527 U.S. 1, 30, 32 (1999) (Scalia, J., concurring in part and dissenting in part) (describing the jury as "the spinal column of American democracy" with a political role that responds to the Founders" "healthy suspicion of the power of government"); Crawford v. Washington, 541 U.S. 36, 67 (2004) (describing the jury system as following from the view that "judges, like other government officers, could not always be trusted to safeguard the rights of the people").

18. See FED. R. EVID. 802.

19. See FED. R. EVID. 609.

20. See FED. R. Evid. 1003.

21. See FED. R. Evid. 403.

22. Laurens Walker \& John Monahan, Social Frameworks: A New Use of Social Science in Law, 73 VA. L. ReV. 559 (1987). These tools do not resolve all concerns about the jury's weaknesses. We still worry about juries faced with the complexities of large-scale litigation governed by complicated laws, and some worry about the "CSI effect," although there seems to be little firm evidence of that effect.

23. See Model Rules of Prof'l R. 3.6 (2011). 
rors' capacities, including those that restrict attorney comments that appeal to racial or other forms of prejudice. ${ }^{24}$ Even longstanding bars against juror note-taking during trial or written copies of jury instructions during deliberations rest on fears that jurors cannot handle these simple tools and somehow will be led astray by them..$^{25}$ In a different respect, speculation that jurors suffer from a "CSI effect"26-that they bring to the courtroom unrealistic expectations for forensic evidence-arises from a presumed naivete that we do not attribute to professional judges. ${ }^{27}$ And the dark side of juries' oft-praised power to nullify (to acquit despite evidence proving guilt) is that jurors sometimes have done so for bad reasons, such as racial bias. ${ }^{28}$

The full picture of the lay jury, then, is somewhat Janus-faced, though it may have an arguable underlying coherence. Juries are poor bodies to determine and define law (a power they lost in the late-nineteenth century $)^{29}$ but well-suited for political judgments that are sometimes inherent in applications of criminal law to particular cases. And while they are generally capable of assessing the credibility of most witness and certain other sources of evidence, ${ }^{30}$ they are susceptible to being misled by emotion or prejudice. On top of that, courts are skeptical of their capacity to identify proof of fault when it requires strong inferences from evidence of conduct and circumstances.

\section{B. Strength and Weaknesses of Judges}

Judges, of course, have a different mix of abilities and weaknesses. The common law tradition and American constitutional doctrine hold a special concern about judges' potential political bias, or their relative weakness (compared to juries), as a check on prosecutors. On the other hand, the common law places great trust in judges to interpret law (and to make common law) and to explain the law to juries. Somewhat less noted, there is also considerable trust in judges as fact-finders. Despite worries about judges' pro-government bias, a number of rules reflect a greater trust in judges' cognitive capacities as compared to lay jurors. Judges, to a greater

24. See id. R. 8.3[3].

25. See United States v. Causey, 748 F.3d 310, 316 (7th Cir. 2014).

26. Kathleen Keough Griebel \& Fred Zain, The CSI Effect, and a Philosophical Idea of Justice: Using West Virginia as a Model for Challenge, 114 W. VA. L. REv. 1155 (2012); The "CSI effect," The Economist, Apr. 24, 2010, at 77; Jeffrey Toobin, The CSI Effect, THE New YORKer, May 7, 2007, at 30.

27. Griebel \& Zain, supra note 26 , at 1155 .

28. See Paul Butler, Let's Get Free: A Hip-Hop Theory of Justice 57-73 (2009) (discussing race-based jury nullification); Doug Linder, Jury Nullification (2001), available at http:/law2.umkc.edu/faculty/projects/ftrials/zenger/nullification.html.

29. See Sparf v. United States, 156 U.S. 51, 97 (1895).

30. See, e.g., Manson v. Braithwaite, 432 U.S. 98, 116 (1977) ("We are content to rely upon the good sense and judgment of American juries, for evidence with some element of untrustworthiness is customary grist for the jury mill. Juries are not so susceptible that they cannot measure intelligently the weight of identification testimony that has some questionable feature."). See generally George Fisher, The Jury's Rise as Lie Detector, 107 YALE L.J. 575 (1997). 
degree than jurors, are governed by rules that trust them to disregard irrelevant information and to sort out unreliable or legally impermissible information. Judges face few, if any, limits related to their exposure to publicity, ${ }^{31}$ and they are more trusted than juries to properly decide cases even after exposure to inadmissible evidence; judges can rule on admissibility and still preside over trial. ${ }^{32}$ Another example is implied in the rule of Bruton v. United States, ${ }^{33}$ which held that jurors cannot be trusted to obey an instruction to consider evidence of a defendant's confession against only that defendant but not his co-defendant in a joint trial. We trust only judges to handle the challenging cognitive task of disregarding known evidence when the evidence is of sufficient significance. The same is true of the Jackson v. Denno rule: juries cannot be trusted to determine whether a confession was voluntary and then, if they were to find it was coerced, to disregard it. ${ }^{34}$

\section{Judicial Comments and Formal Evidentiary Inferences}

These rules reveal a faith that professional judges have greater cognitive capacities of a certain sort than lay jurors. They are part of a common law tradition that takes judges to be in some respects better at assessing evidence than jurors and better at drawing inferences and accurately determining facts. This point is probably less acknowledged in the United States than in England, where the tradition of judicial commentary on evidence remains stronger. But even American law on judicial comments to jurors makes this apparent. The Supreme Court repeatedly has affirmed the power of the trial judge "to assist the jury in arriving at a just conclusion by explaining and commenting upon the evidence, [and] by drawing their attention to the parts of it which he thinks important," including by "express[ing] his opinion upon the facts." ${ }^{35}$ In a classic article, Ronald Allen argued that such judicial comments should be understood

31. In contrast, judges can be disqualified (or should recuse themselves) when some relationship creates the appearance of potential bias, such as ownership of stock in a corporate party, prior involvement in a case as one party's attorney, or (in some cases) having previously accepted financial assistance or contributions from litigants. See, e.g., Caperton v. A.T. Massey Coal Co., 556 U.S. 868, 870 (2009).

32. To be sure, juries are asked to do some of this challenging cognitive work, as well, through evidentiary doctrines that instruct juries to disregard evidence that was wrongly admitted or to use evidence only for one issue but not another.

33. 391 U.S. 123 (1968).

34. Jackson v. Denno, 378 U.S. 368,382 (1964).

35. Quercia v. United States, 289 U.S. 466, 469 (1933) (citing inter alia Vicksburg \& M.R.R. v. Putnam, 118 U.S. 545, 553 (1886)); United States v. Murdock, 290 U.S. 389, 394 (1933) ("A federal judge may analyze the evidence, comment upon it, and express his views with regard to the testimony of witnesses.... [T] he power of the judge to express an opinion as to the guilt of the defendant exists, [but] it should be exercised cautiously and only in exceptional cases."); Horning v. Dist. of Columbia, 254 U.S. 135, 138 (1920) (judge's opinion to jury that defendant was guilty did not require reversal when facts were admitted and undisputed); Starr v. United States, 153 U.S. 614, 622-23 (1894); Simmons v. United States, 142 U. S. 148, 155 (1891) (no error by judge who denied deadlocked jury's request to be discharged and told them "that he regarded the testimony as convincing"); $c f$. Wong v. Smith, 131 S. Ct. 10, 12 (2010) (Alito, J., dissenting from denial of certiorari and describing case law trial judges' discretion to assist jurors by commenting on evidence). 
as another means to provide information to the jury, beyond formal evidence, and also (when comments aid the prosecution) as a functional adjustment in the burden of persuasion. ${ }^{36}$

Much the same can be said of formal rules about evidentiary inferences, which are conveyed to juries through instructions. Inference rules authorize and encourage specific factual inferences from certain kinds of evidence. ${ }^{37}$ One example is the rule that the proof of possession of contraband authorizes an inference of knowing possession; ${ }^{38}$ another is that proof of possession of stolen property is sufficient to infer intent to permanently deprive the owner of the property. ${ }^{39}$ Judicial comments and evidentiary inferences both reflect a judgment, as Allen put it, "that certain facts usually present themselves in a certain relationship, a relationship that may not be known by the jury." 40 The U.S. Supreme Court has endorsed this idea of juries in a number of decisions that approve of both judicial comments and factual presumptions. ${ }^{41}$ "A valid presumption" of one fact from proof of another may, as the Court has put it, "be created upon a view of relation broader than that a jury might take in a specific case." 42 That line of authority accords with a longer common law tradition. ${ }^{43}$

Behind the practice of both judicial comments and instructions on such inferences is an idea that judges (and legislatures, when they codify evi-

36. Ronald J. Allen, Structuring Jury Decisionmaking in Criminal Cases: A Unified Constitutional Approach to Evidentiary Devices, 94 Harv. L. REv. 321, 349-51, n.104 (1980); see also Renee Lettow Lerner, New Trial for Verdict against Law: Judge-Jury Relations in Early Nineteenth-Century America, 71 Notre Dame L. Rev. 505 (1996) (describing various means of judicial influence over jury decisions in 18th and 19th centuries).

37. "In the criminal law, presumptions are used to encourage the jury to find certain facts, with respect to which no direct evidence is presented, solely because other facts have been proved .... The purpose of such presumptions is plain: Like certain other jury instructions, they provide guidance for jurors' thinking in considering the evidence laid before them.... Through the use of presumptions, certain inferences are commended to the attention of jurors by legislatures or courts." Ct. of Ulster Cnty. v. Allen, 442 U.S. 140, 168-69 (1979) (Powell, J., dissenting).

38. See Barnes v. United States, 412 U.S. 837, 854 (1973) (affirming a jury instruction on such a presumption).

39. See, e.g., State v. Schminkey, 597 N.W.2d 785, 793 (Iowa 1999) (Carter, J., dissenting) (citing cases); State v. Rosewell, 239 N.W.2d 171, 173-74 (Iowa 1976). For examples in federal statutes, see, e.g., 18 U.S.C. \$ 1466(b) (2012) (offering to sell two or more obscene articles at one time, or five or more at different times, creates a rebuttable presumption that one is in the business of selling obscene matter); 26 U.S.C. $₹$ 5601(b) (2012) (presence at distillery business is sufficient basis to infer one carries on the business of distillery); 26 U.S.C. $\$ 5681$ (d) (2012) (presence at distillery is sufficient basis to infer one works at distillery).

40. Allen, supra note 36 , at 350 .

41. See Barnes, 412 U.S. at $841-46$ (citing decisions on evidentiary presumptions); Quercia, 289 U.S. at 469 (citing decisions on judicial comments).

42. Tot v. United States, 319 U.S. 463, 468 (1943) (footnote omitted; emphasis added). See also Morrison v. California, 291 US 82, 90 (1934) (evidentiary presumptions properly rest on "the teachings of experience").

43. Matrhew Hale, History of the Common Law of England, 291, 292 (Charles Gray ed., 1971) (describing the trial judge as "able . . . in matters of fact to give [jurors] a great light and assistance by his weighing the evidence before them and observing where the question and knot of the business lies and by showing them his opinion even in matter of fact which is a great advantage and light to laymen."). 
dentiary presumptions) may have superior insight, background knowledge, or "common sense" regarding certain challenging instances of factfinding that jurors do not have. More bluntly, judges can interpret certain kinds of evidence better than jurors. Judges can gain from experience a better ability to draw these factual inferences accurately-a capacity analogous to the "situation sense" that Karl Llewellyn suggested judges possess with regard to legal judgment. ${ }^{44}$ This is one instance of the general theory that human cognition works through "pattern recognition." Experts have better judgment because they have acquired large inventories of patterns or prototypes that allow quick recognition, or cognitive "explanations," for discrete examples. ${ }^{45}$

Judicial comments and factual-inference instructions are both ways for professionals to assist lay fact-finders and so reveal an anxiety about juries' capacity to carry out their central task. Worries about judges' political bias remains; they go too far with these tools and infringe upon the jury's fact-finding autonomy. That concern likewise runs through the case law on evidentiary inferences and judicial comments, and it led many states in the nineteenth century to limit judicial comment by statute..$^{46}$ But the central point is that American courts, following the common law tradition, have long perceived deficiencies in juries' fact-finding abilities that judges are not thought to share. Those deficiencies play a role in the persistence of strict liability, as well.

\section{JURY WEAKNESSES AND STRICT LIABILITY}

\section{A. Strict Liability and Mens Rea Proof Problems}

Save where there is evidence in the form of confessions (including inadvertent ones acquired, for example, from incriminating recordings or emails), evidence of a defendant's mental state must be proven by circumstantial evidence-the sort of inferential fact-finding at which juries

44. Karl N. Llewellyn, The Common Law Tradition: Deciding Appeals 204 (1960).

45. Howard Margolis, Patterns, Thinking \& Cognition \& Dealing with Risk: A THEORY OF JUDGMENT (1987). A classic example is "chicken sexing"-the ability of experienced workers to sort young chicks by gender by sight when most people perceive no difference in the chicks' genitalia. Dan M. Kahan, Science Communication \& Judicial-Neutrality Communication Look the Same to Me, The Cultural Cognition Project at Yale Law School, Nov. 16, 2012, http://www.culturalcognition.net/blog/2012/11/16/science-communi cation-judicial-neutrality-communication-look.html. Police and prosecutors have a similar base of experience to inform their common-sense judgments. Likewise, lawmakers may gain something analogous from the process of legislative fact-finding; at least, that seems to be their conclusion when they codify particular evidentiary presumptions.

46. See, e.g., Turner v. United States, 396 U.S. 398, 405 (1970) (disapproving instruction authorizing factual inference); Quercia, 289 U.S. at 468 (disapproving judicial comment); Murdock, 290 U.S. at 394 (urging caution in judicial comments to juries relating to guilt in criminal cases); Kern v. Levolor Lorentzen, Inc., 899 F.2d 772, 780 (9th Cir. 1990) ("Comments by the judge require reversal if the judge expresses his opinion on an ultimate issue of fact in front of the jury ...."). More generally, see Renee Lettow-Lerner, The Transformation of the American Civil Trial: The Silent Judge, 42 WM. \& MARY L. Rev. $195,245-48,261(2000)$ (describing 19th century state legislation to restrict the judicial comments on evidence in criminal and civil cases). 
are presumed to be especially weak. Given that, it is easy to see how strict liability operates as a stronger means to solve the same problem that evidentiary inferences and judicial comments address - the problem is that juries do not properly recognize inferential facts in the record. Instead of guiding jurors to that inference, strict liability eliminates the need for any inference. If judges always served as fact-finders, their greater abilities to recognize inferential evidence of mens rea would reduce the need for strict liability offenses (and perhaps codified factual presumptions as well)..$^{47}$

It is important to recognize that strict liability need not necessarily impose liability without fault. In some offenses, it plausibly operates instead as an irrebuttable presumption of culpability upon proof of conduct, result, and circumstance elements of the offense. When that presumption is valid, strict liability increases the odds not simply of a conviction, but of a conviction for culpable offenders. One rationale for strict liability in such cases is that a traditional mens rea requirement would risk frustrating appropriate liability because proof of culpability is likely to be overlooked. That risk is greater if we believe that culpability is especially difficult for jurors to recognize. This does not, in my view, account for all strict liability offenses. But it describes a substantial portion of them, at least if one accepts recklessness or negligence as sufficient culpability for criminal liability, as the law in nearly all U.S. states and in England does. ${ }^{48}$

There is plenty of evidence that legislatures and judges authorize strict liability when they conclude that proof-of-conduct elements raise a strong inference of culpability and-somewhat paradoxically-that culpability would be hard for the state to prove..$^{49}$ In decisions on public-welfare or regulatory offenses, courts have long cited "difficulty of proof of knowledge" as justifying strict liability, ${ }^{50}$ yet they add that these offenses ad-

47. Even for judicial fact-finding, we might retain formal rules of inference because we worry about inconsistency in decision-making across cases that these clear-rule strategies could minimize.

48. See, e.g., Model Penal Code \$ 2.02(2) (1981); Mont. Code Ann. § 45-2-103 (2011) (liability requires at least negligence "with respect to each element described by the statute"); Or. Rev. STAT. § 161.115(1), (2) (2011) (same); see also H.L.A. Hart, Negligence, Mens rea, and Criminal Responsibility, in Punishment and Responsibility 136 (1968) (defending negligence as an adequate form of fault).

49. The arguable paradox is that if culpability is so easy to infer from proof of conduct, then it is hard also to conclude that the state would have trouble proving it. The paradox diminishes only on a strong assumption that juries would have a hard time seeing the inference, even though lawyers, judges, and legislators do not. As the examples discussed immediately below suggest, it is not clear that assumption is well-founded.

50. United States v. Balint, 258 U.S. 250, 254 (1922). The seminal strict-liability decision $R v$. Woodrow, [1846] 15 M. \& W. 404, 153 Eng. Rep. 907, widely cited by English and American courts, made the same point about the difficulty of proving mens rea when preventing the harm targeted by the statute is of special importance: "[T] he public inconvenience would be much greater, if in every case the officers were obliged to prove knowledge. They would be very seldom able to do so." For more recent decisions making the same point; see Staples v. United States, 511 U.S. 600, 607, 619 (1994); People v. Stanley, 921 N.E.2d 445, 452-54 (Ill. App. Ct. 2009); State v. T.R.D., 942 A.2d 1000 (Conn. 2008) (making the felony of failing to register as a sex offender a strict liability offense "ensures that a sex offender will not be able to defeat prosecution ... 'simply by claiming he did not 
dress "a type of conduct that a reasonable person should know is subject to stringent public regulation and may seriously threaten the community's health or safety," which suggests that defendants who breach such regulations are at least negligent. ${ }^{51}$

A few examples make the point. For the offense of possessing an illegal weapon in the form of a "sawed off" shotgun, prosecutors must prove a defendant knowingly possessed the weapon but not that he knew the gun's barrel length was shorter than eighteen inches. ${ }^{52}$ Yet anyone who knowingly possesses a weapon surely is aware of its barrel length in a general sense, and one possessing an eighteen-inch barrel is very likely aware, if not of its precise length, at least that it is much shorter than a typical shotgun. From that, it is easy to conclude that one who possesses an eighteen-inch-long shotgun is reckless as to the risk that the barrel is unlawfully short. Proof of knowing possession provides the basis to infer recklessness culpability as to barrel length. This was the Supreme Court's point with regard to possession of hand grenades in United States $v$. Freed ${ }^{53}$ Strict liability for failure to meet a duty to register such a weapon raises an inference of negligence or worse "on the theory that one would hardly be surprised to learn that possession of hand grenades is not an innocent act." ${ }^{54}$ In other offenses the inference may be stronger. The offense of "bookmaking" (defined as "the business of receiving or paying off bets") has been held to be a strict-liability crime. ${ }^{55}$ One is hardpressed to imagine a bookmaker who unknowingly receives and pays gambling bets; proof of the conduct reliably proves state of mind. Indeed, mens rea so obviously accompanies proof of conduct in such cases that strict liability may be superfluous because mens rea is so easy for prosecutors to prove-unless one is worried about juries missing easy inferences that judges and lawyers do not.

A final example can be found in the federal offense of carrying firearms during commission of another crime, which carries a five-year minimum sentence. The statute increases the minimum to ten years for discharging the firearm. ${ }^{56}$ In Dean v. United States, where it was undisputed that the defendant knowingly carried a gun during a bank robbery and accidentally discharged it, the U.S. Supreme Court held that "dis-

know about [the registration requirement], or that he unintentionally overlooked its requirements"); State v. Jordan, 733 N.E.2d 601, 606-07 (Ohio 2000); $R$ v. Sheppard [2003] 1 Cr. App. R. 35 (Rose L.J.) (interpreting Trade Marks Act 1994, § 91(2)(c) and noting mens rea is difficult and costly to prove); $R v$. Wholesale Travelers Grp. [1991] 3 S.C.R. 154, 246-47 (Cory, J.) (Can.) (same).

51. Liparota v. United States, 471 U.S. 419, 433 (1985); see also United States v. Int'l Minerals \& Chem. Corp., 402 U.S. 558, 565 (1971) (reasoning that when dangerous products or obnoxious waste materials are involved, the probability of regulation is so great that anyone who is aware of possessing them is presumed to also be aware of the regulation).

52. Jordan, 733 N.E.2d at 607.

53. 401 U.S. 601,609 (1977).

54. Id.

55. State v. Wac, 428 N.E.2d 428, 431 (Ohio 1981).

56. 18 U.S.C. $\& 924(c)(1)(A)(2012)$. 
charging" was a strict liability element. ${ }^{57} \mathrm{Here}$, too, strict liability attaches only where the state's proof inferentially demonstrates some level of culpability. One who knowingly carries a weapon to a bank robbery is almost certainly at least reckless as to its loaded status and at least negligent as to its unintended discharge. One may disagree that negligence is sufficient culpability for such a sentence enhancement, but strict liability is unlikely to be imposed on actors who used reasonable care as to the strict liability element.

In all these cases, legislatures or courts might have used a device other than strict liability to resolve the challenge of a culpable mental state that they feared jurors could not easily infer. They might assist the state in proving culpable mental states through an evidentiary presumption, or by relying on judges' comments to guide jurors to that inference, or they might put the burden of proof on defendant to show a non-culpable mental state, making strict liability in effect a rebuttable presumption. For offenses in which strict liability follows this usage-proof of conduct raises a reliable inference of culpability-strict liability is merely a stronger device than these alternatives for addressing the challenge to jurors of making that inference. In this sense, concerns about juries lie behind uses of strict liability.

Even if one accepts that strict liability in some offenses such as these applies only to actors whose conduct reveals their culpability, it is certainly the case that, across the broader field of strict liability offenses, this assumption does not always hold. Courts concede as much in offenses ranging from those with strict liability elements regarding a minor victim's age (as in sexual conduct or illicit drug offenses) to regulatory offenses regarding mislabeled drugs and the like. ${ }^{58}$ Strict liability serves aims other than solving difficulties of proving mens rea, notably deterrence, providing special protection to certain interests, and mitigating the magnitude of harms that follow from certain conduct. ${ }^{59}$ Sometimes when emphasizing these justifications for strict liability, courts acknowledge their potential for injustice, which is to say punishing the non-culpable. In the context of these risks, we find intimations of a different relationship

57. 556 U.S. $568,575(2009)$.

58. Some states have general statutes dictating that "[c]riminal intent does not require proof of knowledge of the age of a minor even though age is a material element in the crime in question." See MinN. STAT. \$ 609.02(9) (2009); Wis. STAT. \$ 939.23(6) (2005); see also Kan. STAT. ANN. \$21-5204(b) (Supp. 2011) ("Proof of a culpable mental state does not require proof ... that the accused had knowledge of the age of a minor, even though age is a material element of the crime with which the accused is charged."); N.Y. PENAL LAw $\$ 15.20(3)$ (2009) ("[K]nowledge by the defendant of the age of [a] child is not an element of any ... offense and it is not, unless expressly so provided, a defense ... that the defendant did not know the age of the child ...."). For a public welfare offense regarding mislabeled drugs, see United States v. Dotterweich, 320 U.S. 277, 283 (1943).

59. See, e.g., State v. Rutley, 171 P.3d 361, 365 (Or. 2007) (strict liability justified by statute's goal "to protect children from drug use"); Gorman v. People, 19 P.3d 662, 666-67 (Colo. 2000) (citing, inter alia, the statute's purpose to protect victims as a reason not to infer a requirement that the defendant knows a minor's age in the offense of "contributing to the delinquency of a minor"); State v. Ward, 637 N.E.2d 16, 18 (Ohio Ct. App. 1993) (justifying strict liability on the statute's "purpose of protecting children in schools"). 
between strict liability and the jury, one in which the assumptions shift from the jury's incompetence on particular evidential tasks to its comparative advantage in recognizing the impropriety of convicting the blameless.

\section{PROCEDURAL SAFEGUARDS AGAINST SUBSTANTIVE CRIMINAL LAW}

When strict liability works, not as a means to ensure conviction of the culpable, but as a device serving instrumental ends that also threatens the blameless, substantive criminal law fails to abide by the actus non facit principle. More bluntly, it permits liability on the blameless or disproportionate liability on culpable offenders. As the Court put it in United States $\nu$. Balint, regarding a strict liability felony drug offense, "Congress weighed the possible injustice of subjecting an innocent seller to a penalty against the evil of exposing innocent purchasers to danger from the drug, and concluded that the latter was the result preferably to be avoided."60 (English courts likewise have long admitted that strict liability "may produce mischief in individual cases" by punishing actors who are not at fault. ${ }^{61}$ ) American criminal justice accepts some injustice to non-culpable actors under strict liability in the name of instrumental ends. Yet it is also unwilling to abandon the culpability principle, nor does it expect that strict criminal liability will in practice have widespread effects of punishing blameless actors. The solution is to find and safeguard against injustice, not in criminal law, but in criminal procedure.

American criminal justice is characterized by a strong-at least a formally strong-set of constitutionalized procedures intended to protect defendants subjected to criminal prosecution, all of which are found, with moderate doctrinal variations, in England and other common-law nations as well. The Sixth Amendment alone includes the right to a speedy public trial by an impartial jury, limits on the district from which jurors may be drawn, and rights to sufficient notice regarding charges, to present evidence through compulsory process, to confront state witnesses, and to be assisted by defense counsel. The Fifth Amendment adds guarantees to an indictment by a grand jury for serious crimes, limited double jeopardy protections against being tried or punished twice for the same offense, and the right not to testify. The Eighth Amendment adds limited protections against excessive bail requirements before trial and against excessive punishment after conviction. ${ }^{62}$ Over the last several decades, the Due Process Clauses of the Fifth and Fourteenth Amendments have become sources of further protections, notably the bar on involuntary confessions, the prosecutor's duty to disclose exculpatory evidence to defendants, and

60. U.S. v. Balint, 258 U.S. $250,253-254$ (1922).

61. State v. Balt. \& Susq. Steam Co., 13 Md. 181, 187 (1859); $R$ v. Woodrow, 15 M. \& W. at 417 .

62. U.S. Const. amends. V, VI, VII \& XIV; see also art. III $\S 2$ ("The trial of all crimes, except in cases of impeachment, shall be by jury"). 
the state's high standard of proof, and limits on racially motivated juror selection and (formally, though not practically) prosecutorial charging discretion. ${ }^{63}$ Most of these federal provisions (save the grand jury) apply in state as well as federal courts. State governments duplicate most in their own constitutions and sometimes add additional safeguards (such as a right to bail). ${ }^{64}$ Statutory law further regulates the criminal process by specifying evidence discovery and disclosure powers, allocating peremptory strikes to parties during jury selection, granting multiple opportunities for appellate review, and more.

These procedural guarantees, rooted in traditions of the common law and adversarial process, are less distinctive as compared to other criminal process elsewhere than they once were. The post-World War II European Convention on Human Rights includes a substantially similar set of guarantees (with the notable exception of the right to a jury trial). ${ }^{65}$ But the United States from its beginning has favored a distinctive reliance on procedure rather than substantive limits or requirements-in particular, $a d-$ versarial procedure - as a bulwark against unjust criminal punishment. The familiar story is that the animating purpose of constitutional criminal procedure is to serve as safeguard against government abuse of power and thereby protect individual liberty and to effectuate the constitutional commitment to democratic governance in the judicial branch and the adjudication process. ${ }^{66}$ To fulfill these ambitions, constitutional procedural requirements-in the view of many, notably including some recent justices-implicitly mandate core features of adversarial, rather than inquisitorial, adjudication process. The inference (and premise) is that adversarial process itself provides strong protections to defendants. ${ }^{67}$ In general, especially in the wake of Warren Court era, the dominant narrative of American criminal justice, for most Supreme Court justices and some commentators, is that criminal defendants enjoy strong (perhaps excessively strong) procedural protections. ${ }^{68}$

63. Brady v. Maryland, 373 U.S. 83,95 n.5 (1963); In re Winship, 397 U.S. 358,358 (1970); Batson v. Kentucky, 476 U.S. 79, 79 (1986); United States v. Armstrong, 517 U.S. 456, 464 (1996).

64. Adriana Lindermayer, What the Right Hand Gives: Prohibitive Interpretations of the State Constitutional Right to Bail, 78 Fordham L. Rev. 267 (2009) (exploring the right to bail across several states).

65. British Institute of Human Rights, British Institute of Human Rights Fact Sheet: The European Convention on Human Rights (2013), http://www.bihr .org.uk/sites/default/files/BIHRECHR60AnnFactsheet_0.pdf. (1997)

66. Akhil Amar, The Constitution and Criminal Procedure: First Principles

67. David Sklansky, Anti-Inquisitorialism, 122 HARv. L. Rev. 1634 (2009); Crawford v. Washington, 541 U.S. 36 (2004).

68. See Missouri v. Frye, 132 S. Ct. 1399, 1413 (2012) (Scalia, J., dissenting); Lafler v. Cooper, 132 S. Ct. 1376, 1392 (2012) (Scalia, J., dissenting); Albert Alschuler, Lafler and Frye: Two Small Band-Aids for a Festering Wound, 51 DuQUESNE L. Rev. 673 (2013) (criticizing Scalia on this point). For an argument about excessive criminal procedure protections, see Paul G. Cassell, Miranda's Social Costs: An Empirical Reassessment, 90 Nw. L. REV. 387 (1996). For a Supreme Court description of trade-offs between constitutional rights and effective criminal law enforcement, see, e.g., United States v. Ruiz, 536 U.S. 622 , 623 (2002). 
This regime of procedural safeguards is accompanied by the Constitution's notable lack of parameters for substantive criminal law or punishment. Save for limits that follow as corollaries from guarantees of free expression, gun ownership, or personal privacy, the Constitution places almost no constraints on what legislators may criminalize or how they may define offenses. ${ }^{69}$

This combination of strong procedural protections and weak limitations on substantive criminal law reveals the American strategy for guarding against the risks posed by strict liability (and also reverse-proof burdens) - the risks that liability will not correspond with culpability. Our criminal justice system relies comparatively more on procedure and comparatively less on criminal law to prevent unjustified punishment. Judges and legislators take criminal procedure as a substantial and largely sufficient means to prevent the injustice of criminal liability without culpability, even under a criminal code that formally authorizes it. If procedural protections provide a meaningful bulwark against government punishing the non-culpable, then strict criminal liability poses less risk of injustice; mens rea requirements, on this view, can seem like an unnecessarily redundant safeguard. Moreover, they would be costly ones. As we have noted, strict liability removes difficult proof problems the state would otherwise face. It also helps to solve, in the Supreme Court's view, inevitable challenges of legislative drafting-the "treacherous[ness]" and "mischievous futility" of trying to codify precisely "a formula embracing the variety of conduct" targeted by certain offenses. ${ }^{70}$ In those offenses for which proof of conduct alone demonstrates culpability, creating those proof problems (by adding mens rea requirements) could mean frustrating the state's ability to convict the culpable and the broader public interest in effective law enforcement. If one accepts the premise that criminal procedure already provides sufficient protection against injustice, that frustration is unnecessary. We don't need uniform, stringent mens rea requirements on top of a strong procedural regime.

Thus, while some nations-notably Germany but also Canada, which shares with the United States a system of adversarial process with common law juries-have largely abolished strict criminal liability, as well as reverse proof burdens, in reforms aimed at reducing risks of unjust punishment, the American criminal justice system (like that of England)

69. For examples of substantive limits on criminalization, see, e.g., McDonald v. Chicago, 561 U.S. 3025,3110 (2010) (second amendment restricts state regulation of private gun ownership); United States v. Stevens, 559 U.S. 460,465 (2010) (overturning federal crime for depictions of animal cruelty); Lawrence v. Texas, 539 U.S. 558, 562 (2003) (striking down criminal prohibition of sodomy); Griswold v. Connecticut, 381 U.S. 479, 480 (1965) (invalidating criminal prohibition on contraceptives for married persons); Robinson v. California, 370 U.S. 660,660 (1962) (rejecting criminalization of drug addiction as a personal status). For examples of substantive limits on punishment under the Eighth Amendment, see, e.g., Roper v. Simmons, 543 U.S. 551, 578 (2005) (barring death penalty for offenders under age 18); Atkins v. Virginia, 536 U.S. 304, 321 (2002) (barring death penalty for mentally retarded offenders). See also U.S. CoNST. art. III, $\$ 3$ (prohibiting "corruption of blood"-limits on inheritance rights-as a sanction for treason).

70. United States v. Dotterweich, 320 U.S. 277, 285 (1943). 
seems confident that the strength of its procedural regime prevents most of the excesses made possible by reliance on strict liability.

If that is true, what procedural components in particular do courts expect to provide much of this protection from the potential injustice of strict criminal liability? The two most significant are also two that may seem the most implausible. One is prosecutorial discretion. The other is the very institution whose dubious fact-finding abilities contribute to the need for strict liability in the first place: the jury.

Prosecutors can be a safeguard against unjust strict liability because they have discretion to withhold charges unless justified by policy or public interest as well as factual sufficiency. Broad prosecutorial discretion is the longstanding tradition in the all common law countries (and some civil law ones). ${ }^{71}$ That discretion is especially strong in the United States. ${ }^{72}$ And courts take this broad executive authority as a safeguard against the implications of strict liability rather than an avenue through which it might be exploited. U.S. courts, despite occasionally expressing concerns about abuses of prosecutorial power in other settings, generally assume that prosecutors will use their discretion prudently so as not to charge strict liability crimes unless merited by defendant's culpability. Instead of worrying that strict liability will be the prosecutor's instrument for abuse, prosecutorial discretion is viewed as a safeguard that makes strict liability feasible. The solution for the overbreadth of strict liability, the Supreme Court has noted, is the criminal justice system's reliance on the "conscience and circumspection in prosecuting officers." 73 Legislatures draft strict liability crimes and other overbroad offenses "against a background assumption of prosecutorial discretion." 74

Additionally, courts continue to trust juries as well—especially with the aid of trial judges - to prevent injustices from strict liability offenses, despite skepticism about jurors' abilities to handle certain fact-finding challenges and evidentiary inferences. The judicial logic is unclear on this point, but it seems to rest in part on a sense that juries are more likely to err by acquitting (as when they inaccurately fail to infer a defendant's

71. The oft-cited English statement of this principle was made by Lord Shawcross while Attorney General: "It has never been the rule in this country-I hope it never will be-that suspected criminal offences must automatically be the subject of prosecution." See Office of the DPP, http://www.dpp.gov.fj/default.aspx?page=decisionProsec [original citation: House of Commons Debates, Official Report, 29 Jan. 1951; Vol. 483, col. 681.] [Alternate cite: Gary Slapper \& David Kelly, The English Legal System: 2009-2010, available on books.google.com] For an international survey of prosecutorial authority; see Erik Luna \& Marianne L. Wade, eds., The Prosecutor in Transnational Perspective (2012).

72. English courts exercise occasional authority to overturn charging or non-charging decisions in circumstances and on grounds that American judges would not. See $\mathrm{R}$ (on application of Guest) v. D.P.P. E.W.H.C. 594 (2009); R v. Inland Revenue Commissioners, ex parte Mead 1 All ER 772 (1993) (review of decision to prosecute); $R v$. Gen. Council of the Bar, ex parte Percival 3 All ER 137 (1990) (review of non-prosecution decision); see also C. Hilson, Discretion to Prosecute and Judicial Review, CRIM. L.R. 739 (1993). 285.

73. Nash v. United States, 229 US 373, 378 (1913), quoted in Dotterweich, 320 U.S. at

74. Abuelhawa v. United States, 129 S. Ct. 2102, 2107 n.3 (2009). 
culpable mental state from circumstantial evidence) than by convicting when a defendant is insufficiently culpable. This is in my view a dubious assumption for which there is little or no empirical evidence, but courts generally seem not to share that skepticism. And the opposing view is a rational one: Juries may have certain fact-finding deficiencies yet at the same time retain a reliable "common sense" regarding whether a prosecution is just (i.e., whether conviction is deserved). On this view, jurors' normative instincts—or, put differently, political judgment-provide a safeguard against unjust conviction even though jurors' weaker fact-finding abilities with respect to mental states means they will sometimes overlook evidence of mens rea that judges would recognize. This vision of jury competency makes sense of the Supreme Court's confidence that strict liability will lead to just outcomes despite its obvious risks. We can rest easy, the Court assures us, because strict liability's application is overseen by "the good sense of prosecutors, the wise guidance of trial judges, and the ultimate judgment of juries." 75

In sum, strict liability offenses, along with reverse-burden rules, endure because confidence in the procedural regime reduces the need for greater precision in substantive law. In fact, when faced with the fact that AngloAmerican criminal law employs strict liability far more broadly than one finds elsewhere, American lawyers, judges, and policymakers nonetheless might not concede that their system has a weaker commitment to punishing on the basis of culpability than does the criminal justice system in Germany or elsewhere. They might instead have confidence that the common law and adversarial process traditions provide a different route to achieving that same objective.

\section{CONCLUSION}

It seems that a curious combination of anxiety about and confidence in the lay jury has played a role in sustaining Anglo-American strict criminal liability. The jury is surely not the only reason for the persistence of these rules in Anglo-American criminal law. It might not even be a necessary one inasmuch as, if we had no juries, other reasons still might prove sufficient to justify some instances of strict liability. Especially when it is rebuttable, strict liability (like reverse burdens generally) encourages defendants to produce evidence that is sometimes in their singular con-

75. Dotterweich, 320 U.S. at 285 . Note that the reliance here on the "judgment of juries" illustrates confidence that they will appropriately favor defendants. Elsewhere, the concern about jurors' competence in fact-finding is also one in which jurors will favor defendants-but inappropriately, as a result of fact-finding errors. See also Evans v. United States, 504 U.S. 255, 296 (1992) (Thomas, J., dissenting) ("Our criminal justice system runs on the premise that prosecutors will respect, and courts will enforce, the boundaries on criminal conduct set by the legislature."); Smith v. United States, 411 U.S. 952, 954 (1973) (Douglas, J., dissenting from denial of certiorari) (noting "the virtually unreviewable prosecutorial discretion concerning the initiation and scope of a criminal prosecution"); Ashe v. Swenson, 397 U.S. 436, 452 (1970) (Brennan, J., concurring) (noting "our tradition of virtually unreviewable prosecutorial discretion concerning the initiation and scope of a criminal prosecution"). 
trol. Perhaps, jurisdictions in which law enforcement has greater abilities to interrogate defendants have less need for such devices (although the practical abilities of American officials to interrogate and eavesdrop on suspects despite the privilege against self-incrimination may leave little left to be gained from an additional power to question suspects under oath). Anglo-American criminal law may also simply have a greater consensus around a weaker conception of culpability. Despite the objections of many scholars, much of Anglo-American criminal law manifests the idea that causation of harm alone is sometimes sufficient to justify punishment and quite often sufficient to greatly aggravate punishment for one who is culpable for some lesser offense. ${ }^{76}$ Nonetheless, the intractable presence of the jury (for the small percentage of cases not resolved by guilty pleas) seems to play a role as well.

More generally, the recognition that procedural forms such as juries affect substantive law provides another example of the complex interactions of law, procedure, institutional design, and the background assumptions about each. That recalls a familiar peril of comparative legal analysis: the risk of assessing a single rule or practice among systems without taking account of the different settings in which they operate. The same lesson applies to consideration of rules within a single legal system. Strict liability is not solely a function of normative debates over whether culpability is required for just punishment or whether that principle is trumped by instrumental aims. Strict liability also hinges on, among other things, faith in the procedures by which we determine culpability.

76. For an argument to this effect, see Brown, supra note 9. 
